\title{
L1 transfer in the acquisition of manner and path in Spanish by native speakers of English
}

Article

Accepted Version

article in refereed international journal

Larrañaga, P., Treffers-Daller, J., Tidball, F. and Gil Ortega, M.c. (2012) L1 transfer in the acquisition of manner and path in Spanish by native speakers of English. International Journal of Bilingualism, 16 (1). pp. 117-138. ISSN 1756-6878 doi: https://doi.org/10.1177/1367006911405577 Available at https://centaur.reading.ac.uk/20654/

It is advisable to refer to the publisher's version if you intend to cite from the work. See Guidance on citing.

To link to this article DOI: http://dx.doi.org/10.1177/1367006911405577

Publisher: Sage

All outputs in CentAUR are protected by Intellectual Property Rights law, including copyright law. Copyright and IPR is retained by the creators or other copyright holders. Terms and conditions for use of this material are defined in the End User Agreement.

www.reading.ac.uk/centaur 
Central Archive at the University of Reading

Reading's research outputs online 
Transfer in manner and path in L2 Spanish

L1-transfer in the acquisition of manner and path in Spanish by native speakers of English

Pilar Larrañaga ${ }^{1}$, Jeanine Treffers-Daller ${ }^{2}$, FrançoiseTidball ${ }^{2}$ and Maricarmen Gil Ortega ${ }^{2}$

${ }^{1}$ Universität Wuppertal \& ${ }^{2}$ University of the West of England, Bristol

Address for correspondence

Jeanine Treffers-Daller

University of Reading, Institute of Education.

Email: j.c.treffers-daller@reading.ac.uk

Email: Pilar Larranaga: fermin@gmx.net

Running head:

Transfer in manner and path in L2 Spanish 
Transfer in manner and path in L2 Spanish

\begin{abstract}
In this paper we argue that L1 transfer from English is not only important in the early stages of L2 acquisition of Spanish, but remains influential in later stages if there is not enough positive evidence for the learners to progress in their development (Lefebvre, White and Jourdan, 2006). The findings are based on analyses of path and manner of movement in stories told by British students of Spanish $(\mathrm{N}=68)$ of three different proficiency levels. Verbs that conflate motion and path, on the one hand, are mastered early, possibly because the existence of Latinate path verbs, such as enter and ascend in English, facilitate their early acquisition by British learners of Spanish. Contrary to the findings of Cadierno (2004) and Cadierno and Ruiz (2006), the encoding of manner, in particular in boundary crossing contexts, seems to pose enormous difficulties, even among students who had been abroad on a placement in a Spanish-speaking country prior to the data collection. An analysis of the frequency of manner verbs in Spanish corpora shows that one of the key reasons why students struggle with manner is that manner verbs are so infrequent in Spanish. We claim that scarce positive evidence in the language exposed to and little or no negative evidence are responsible for the long lasting effect of transfer on the expression of manner.
\end{abstract}

\title{
1. Theoretical considerations
}

Most research in SLA has been devoted to formal issues that are tightly linked to the issue of Universal Grammar and have, therefore, looked at syntactic and phonological phenomena (Trujillo, 2001) to quote but just a recent one. Recently the interface between semantics and syntax in the L2 acquisition of Spanish has been studied by White, Valenzuela, KozlowskaMacgregor \& Leung (2004) amongst many others whereby the main focus of the research was the interface between semantics and syntax in the acquisition of gender. Only recently have the acquisition of concepts and the conceptualization of events become interesting for 
Transfer in manner and path in L2 Spanish

researchers working in the field of second language acquisition, and most notably for those working in the generative framework. However, scholars working in cognitive linguistics have a long standing tradition of studying meaning and conceptual structure (Langacker 1999; see Robinson \& Ellis, 2008 for an overview).

In the present paper we will be dealing with conceptual elements that are supposed to be universal primitives, although the mapping of these elements onto lexical items and syntactic phrases varies across languages. The issues that will be analyzed here are what role L1 plays in L2 acquisition and the impact of positive and negative evidence in the acquisition of the expression of motion. In our study we build on the important work of Cadierno (Cadierno, 2004, 2008a, 2008b, Cadierno \& Lund, 2004, Cadierno \& Ruiz, 2006) with Danish learners of Spanish.

Let us briefly consider a few general theoretical issues related to first and second language acquisition, most importantly the issue of transfer, positive and negative evidence. First language acquisition (FLA) and second language acquisition (SLA) contrast in many respects, notably with respect to initial and attained end state. Whilst first language learners reach a native-like competence, adult SL learners do not attain this goal in most cases (Birdsong, 2005; Bley-Vroman, 1989; Johnson \& Newport, 1989; Lardiere, 2007). Even if grammar is native-like, a foreign accent remains in most cases (Trujillo, 2001). As to the initial state, researchers do not agree what the initial state in FLA is, but scholars in the field of SLA research agree that the initial state in SLA is the L1 (mother tongue). However, the role the L1 plays in the course of SLA is very controversial. Schwartz \& Sprouse (1996) suggest that the full structure of the L1 is transferred to the L2 and that this forms the initial state in SLA. Other authors state that the L1 affects not only the initial state but remains influential if there is not enough positive evidence for the learner to progress in his/her development (Lefebvre, White \& Jourdan, 2006). This would explain the occurrence of target-deviant structures in the interlanguage (IL) and the step by step implementation of 
Transfer in manner and path in L2 Spanish

different features and structures in L2. The target-deviant structures or errors are often copies of structures of the L1, a phenomenon that is known as transfer.

In her study of motion events among Danish L2 learners of Spanish, Cadierno (2004) finds some evidence for L1 transfer in the complexity and elaboration of path of motion, but her informants did not conflate manner and motion in the verb in boundary crossing contexts, which would have been expected if L1 transfer is a major factor in L2 acquisition. In a follow-up study, Cadierno \& Ruiz (2006) do not find evidence for L1 transfer in L2 expressions of manner either. Cadierno (2008a, p. 265) therefore comes to the conclusion that the influence of the L1 in the expression of motion is stronger at the initial and intermediate stages but that learners at an advanced stage in second language acquisition are able to express motion in target-like ways. Phillips (2003) finds some evidence for L1 transfer in frog stories told by American learners of Spanish, in particular among beginners. In sum, learners of S-languages such as Danish or English do indeed transfer some structures of their L1 while learning a V-language as their L2, but the role of transfer still remains controversial. Transfer may well be triggered by partial overlap of argument structures between languages (Adjémian, 1984, White, 1991; Inagaki, 2001), and this is particularly interesting for the current study, because there is indeed considerable overlap between the expression of motion in Spanish and English, as we will see in section 2.

Any learner acquiring a second language needs positive evidence in order to achieve a given degree of proficiency, but some structures cannot be acquired without access to negative evidence, that is information about the ungrammaticality of particular utterances. As White (1991) has shown in her study of the acquisition of dative structures by Englishspeaking learners of French, learners who are acquiring an L2 which is a subset of the L1 with respect to particular argument structure properties experience great difficulty in acquiring the target language structure, because they need negative evidence to find out which structures 
Transfer in manner and path in L2 Spanish

are impossible in the L2. In English both (1a) and (1b) are allowed, but in French only (2a) is allowed, which makes French a subset of English at this point.

1) a. John gave the book to Mary.

b. John gave Mary the book.

2) a. Jean a donné le livre à Marie.

b. *Jean a donné Marie le livre.

White (1991) found that learners of French whose L1 was English still accepted forms like (2b) after many years of exposure to French, which confirms the subset hypothesis. Inagaki (2001) applies this model to the analysis of motion. Japanese is a subset of English in that it does not allow directional readings of manner verbs with prepositional phrases. Thus, while in English John swam under the bridge can be interpreted to indicate either the location of John's swimming or the goal of his action, only the locational interpretation is possible in Japanese. In a bidirectional study of Japanese learners of English and English-speaking learners of Japanese, Inagaki shows that Japanese learners were able to find out from positive evidence that manner-of-motion verbs can be used with goal PPs in English, whereas Englishspeaking learners of Japanese found it very difficult to learn that manner-of-motion verbs cannot be accompanied by goal PPs in Japanese, because nothing in the input will tell them so.

Birdsong (1987) makes the observation that negative evidence exists but it is difficult to quantify in everyday life and even in the classroom. Moreover, the usefulness of negative evidence to learners very much depends on their metalinguistic awareness which is linked to literacy. Birdsong reports that illiterate speakers have an impoverished ability to detect negative evidence. The study of Montrul \& Bowles (2008) confirms that it is difficult to study the impact of negative evidence experimentally. In their study, thirteen heritage speakers in 
Transfer in manner and path in L2 Spanish

the USA and twelve native speakers of Spanish were presented with positive and negative evidence about the rules for differential object marking (the use of the preposition $a$ for accusative) in Spanish. Their results were not very conclusive in that they could not ascertain how much of the success was due to positive and how much to negative evidence.

Positive evidence is difficult to quantify and assess, since curricular as well as extracurricular positive evidence may influence ultimate attainment. Exposure to the target language may include a variety of sources such as reading newspapers, watching TV or a visit to the target country. Despite methodological difficulties to assess the impact of the different sources Al-Ansari (2001) conducted an interesting study in Bahrain amongst 94 students enrolled in different University degrees in order to assess the impact of curricular and extracurricular language exposure. The sociolinguistic context in Bahrain is such that around 25 percent of the population are expatriates who speak English in everyday situations and students have plenty of opportunities to listen to English in their social interactions, at home and at University. Al-Ansari (2001) shows that there is no causal link between exposure to extracurricular target language and performance measured by the composition and listening comprehension, although the extracurricular exposure did have an impact on the cloze-test. In other words, low level learners performed less well than high performers in all tests independently of their extracurricular exposure. He argues that low performers may not benefit from the extracurricular input because the level they are exposed to may be too high for them to assimilate this knowledge.

An issue worth exploring is whether the frequency of the studied structures in the input has an impact in the learners' output. Of course frequency cannot be assessed by self-report, and recording the entire exposure of a learner over a given period of time is a utopic enterprise. One way to obtain information about the input any learner may be exposed to is to search words or lemmas under investigation in a large database. To our knowledge this approach has not yet been applied to the analysis of motion in L2 acquisition. In order to 
Transfer in manner and path in L2 Spanish

obtain an idea of the frequency of the target verbs investigated in this paper, we will look at usage of path and manner verb frequencies in the Davies corpus.

As we have explained above, the issue of negative evidence is of utmost importance for the present study, but the problem for our learners is that teachers tend not to present ungrammatical sentences in class, which would be one way to make negative evidence explicit. Negative evidence is in general not available because nothing makes the learner aware of an ungrammatical utterance unless s/he is learning the foreign language in an institutional environment and the teacher corrects an error or makes an explicit comment on a given structure. Learners may be confronted with negative evidence in the classroom when they listen to the language of their peers, but any teacher of Spanish knows that it is good practice not to correct every error produced by learners. And more importantly, any teacher of Spanish would concentrate on core aspects of Spanish grammar when correcting errors, and the domain of motion verbs does not belong to this area of grammar. We assume that our participants have metalinguistic awareness because they are all university-level language students, although we agree with Birdsong (1987) that a wide range of variation in students' ability to detect and learn from errors can be expected. Even if errors are corrected, resulting in explicit negative evidence, it is far from clear whether this negative evidence will have an overall positive impact on language abilities in the long term. To give just one example, teachers of Spanish language report that the word problema is persistently used with the article $l a$, which is target deviant. They also report that this word is repeatedly corrected in the Spanish lessons, apparently with little success. Thus, massive exposure to negative evidence does not warrant the expected success in domains which are classified as very resistant. Some domains are so resistant that they fossilize regardless of the amount of input or negative evidence. It is not clear whether negative evidence in the domain of motion verbs would have any impact on the learning task to be achieved. In sum, learners in the present study were confronted with negative evidence more or less consistently in their classroom but 
Transfer in manner and path in L2 Spanish

this exposure was linked to the core grammar, according to the reports of the lecturers. L2 learners of Spanish with English as their L1 need positive and specific negative evidence to acquire the target-like expression of motion.

So then, what is the goal the learners need to achieve in order to implement the notion of motion and path as well as manner in Spanish? We agree with Stringer (2005, p. 594) that it is not sufficient to learn the general rules for the expression of motion, because L1 and L2 learners also need to acquire the argument structure associated with particular lexical items. In other words, learners must learn which elements denoting motion are mapped onto the satellites and whether these elements occur in form of PPs, adverbs, gerunds, particles etc. for each particular lexical item, and if there are any restrictions (e.g. the boundary crossing constraint) on the use of these constructions. In the current study we therefore decided to focus on a very narrow range of verbs that can be used to describe a particular motion event which involves a boundary crossing.

The empirical evidence presented above as well as the theoretical considerations briefly sketched lead us to assume with Lefebvre, White \& Jourdan (2006) that the L1 remains influential if there is not enough positive evidence in the input and negative evidence is only cursorily available for the learner to progress in his/her development. In the case of the L2 acquisition of the expression of motion in Spanish, this means that L1 transfer should reveal itself in a number of structures for which British learners cannot find positive evidence (e.g. structures in which the boundary crossing constraint applies).

\section{Motion event construals in English and Spanish}

In the present article we use Talmy's $(1985 ; 2000 \mathrm{a} / \mathrm{b})$ framework for the description of a motion event. According to Talmy (1985, p. 60-61), “The basic motion event consists of one 
Transfer in manner and path in L2 Spanish

object (the 'Figure') moving or located with respect to another object (the reference object or 'Ground')." The motion event has four internal components: the Figure, the Ground, path and motion. In addition to that the Cause or the manner of a motion can be expressed in what is considered to be an external event in Talmy's (1985) framework. Languages differ considerably as to the means they use to map these conceptual elements onto surface expressions. This observation has led researchers such as Talmy $(1985,2000 \mathrm{a} / \mathrm{b})$ and Slobin (2004) to propose a typology of languages according to how the information is packaged. Talmy classifies languages in Satellite-framed (S-framed) and Verb-framed (V-framed). Languages such as English or German are called S-framed, because in these languages path tends to be mapped onto satellites or prepositions which are added to the verb, for example $g o$ into, go in, go up, go down. Languages such as Spanish, Turkish or French are called Vframed because they encode path in the verb as in entrar 'go in', salir 'come out', bajar 'go down', subir 'go up'. S-framed languages tend to conflate manner and motion in the main verb and map path onto a satellite, as in (3) and (4).

(3) Leire $\operatorname{ran}_{[\text {motion }+ \text { manner] }}$ out $_{[\text {path] }}$

(4) Iñaki ran [motion + manner] $_{\text {[path] }}$ the market ${ }_{\text {[ground] }}$

In V-framed languages, by contrast, path and motion are conflated in the main verb, and - if manner is expressed at all - it is mapped onto an adjunct, as in (5-8).

(5) Iñaki se fue ${ }_{[\text {motion }+ \text { path] }} \operatorname{corriendo}_{[\text {manner] }}$ al mercado ${ }_{\text {[ground] }}$

'Iñaki went running to the market.'

(6) Iñaki subió ${ }_{[\text {motion + path] }}$ corriendo $_{[\text {manner] }}$ a la azotea ${ }_{[\text {ground] }}$ 
Transfer in manner and path in L2 Spanish

'Iñaki ran up to the roof.'

(7) Leire salió $\left[\right.$ motion + path] corriendo $_{[\text {manner] }}$

'Leire ran away.'

(8) ${\text { Leire } \operatorname{vino}_{[\text {motion + path] }} \text { corriendo }}_{[\text {manner }]}$

'Leire came running.'

According to Beavers, Levin \& Tham (2010), however, in most languages both Satelliteframed and Verb-framed patterns are available. The authors argue that motion patterns can be attributed to motion-independent morphological, lexical and syntactic resources in each language and that extra-grammatical (contextual) factors explain why a particular pattern is preferred in a particular situation. Similar criticisms of Talmy's model can be found in a study of caused motion in Chinese (Hendriks, Ji \& Hickmann, 2009). Talmy (1985, p. 62) does recognize the existence of alternative patterns in each language, but claims that "any language uses only one of these types for the verb in its most characteristic expression of motion". The notion "characteristic" refers to patterns that are colloquial, frequent and pervasive in a language. Such patterns are indeed observed in the analyses Berman \& Slobin (1994) and Slobin (1996) make of the frog story (Mayer, 1969). They show that the scene of the owl coming out of the tree is lexicalized in different ways by Spanish and English speaking participants. In their analysis of the speech productions of children and adult Turkish, Spanish and English speakers Özçalışkan \& Slobin (1999) show that the overall use of path and manner verbs remains constant across ages within one and the same language. S-language speakers show a higher frequency and greater lexical diversity of manner verb use, as compared to V-language speakers (Özçalışkan \& Slobin, 2003, p.260). However, some differences among V-framed languages emerge. In fact, speakers of Turkish use a wider 
Transfer in manner and path in L2 Spanish

variety of path verbs than Spanish speakers. Moreover, they observe that Turkish and Spanish speakers never use manner verbs to refer to the owl coming out of the hole, whilst English speakers use manner verbs in $32 \%$ of the cases. While the former choose to use verbs such as salir or aparecer "exit" in Spanish in all instances in this particular scene, the latter use verbs with a satellite such as pop out, fly out. Özçalışkan \& Slobin (2003, p. 259) contend that encoding manner in the satellite increases the processing load, and therefore manner is only expressed in V-languages when it is foregrounded. In addition, in as far as the expression of path of motion is concerned, speakers of V-languages such as Spanish tend to use bare motion verbs, and do not elaborate on the path "beyond the inherent directionality of the verb itself" (Slobin, 1996, p. 200). In English, locatives and directionals are often added to motion verbs.

Importantly, in their analysis of frog story data, Slobin \& Hoiting (1994) note that the verb "fly" is never used by speakers of V-framed languages in order to refer to the owl coming out of the hole. The scholars suggest that this is not only due to the fact that Spanish is a V-language and speakers of V-languages prefer to use path verbs, but also because "verbframed languages only license the use of a manner verb as a main verb if no boundary crossing is predicated" (Slobin, 2006, p. 67). In V-framed languages it is acceptable to fly to/from the tree but not to fly into/out of the hole ${ }^{i}$. Boundary crossing events involve changes of state and in V-languages the main verb must encode the change of state (exit, enter, cross, etc.). In S-framed languages this constraint does not apply. Within one clause manner can be expressed in the main verb and path can be mapped onto a satellite, whether a boundary is crossed or not (9-10).

(9) He ran to the house [- boundary crossing]

(10) He entered/ ran into the house [+ boundary crossing] 
Transfer in manner and path in L2 Spanish

In V-languages manner of motion can be incorporated to the verb when the Figure does not cross a boundary, as in (11) and (12), but it must be mapped onto a satellite when a boundary is crossed, as in (13-14).

(11) Corrió [motion + manner] hacia la estación de autobuses [-crossing]

'(She) ran to the bus station.'

(12) Ella se tambaleó ${ }_{[m a n n e r]}$ al hospital

'She staggered to the hospital.'

(13) Entró $[$ motion + path] corriendo [manner] a la estación de autobuses [+crossing]

'(She) ran into the bus station.'

(14) Subió ${ }_{[m o t i o n}+$ path] a la estación de autobuses andando ${ }_{[\text {manner] }}$

'(She) walked up to the bus station.'

Feist, Rojo \& Cifuentes (2007) show, however, that speakers of Spanish more readily accept manner-of-motion verbs in boundary crossing events in Spanish when manner has been made artificially salient.

The distinction between path and manner verbs may also not be fine-grained enough. In her study of path and manner of motion in Spanish, Morimoto (2001; cited in Phillips, 2003, p. 29), distinguishes two types of manner of motion Verbs. On the one hand, the category of Internal manner of motion (VMMIs—Verbos de «Manera de Moverse» Interna) includes verbs such as patalear 'to stomp,' balancearse 'to swing,' and bailar 'to dance,' which express a type of manner of motion produced autokinesthetically, or reflexively: the trajectory and the Ground remain unspecified. Verbs that belong to the second type, on the other hand, External manner of motion (VMMEs_Verbos de «Manera de Moverse» Externa), such as correr 'to run,' caminar 'to walk', andar ,to walk' and volar 'to fly,' can reference trajectory and path PPs can follow them. VMMEs also differ from VMMIs in that the former express an 
Transfer in manner and path in L2 Spanish

element of displacement, whereas the latter do not, as shown in (15) and (16). We will be only concerned with the latter in this paper since the former are not used by the learners.

(15) *Bailamos muchos metros.

'We danced many meters.' (Morimoto, 2001, p. 49, cited in Phillips, 2003, p. 30)

(16) Caminamos $[$ manner] muchos metros.

'We walked many meters.' (Morimoto, 2001, p. 49, cited in Phillips, 2003, p. 30)

According to Phillips (2003, p. 31), these two categories of manner verbs should be considered separately, as their behavior is clearly distinct. This is particularly important for the L2 acquisition of motion event construals, because "Talmy's (1985) typology does not necessarily account for all the problems L2 Spanish speakers must contend with; rather, it is the differences between VD [verbs of displacement; ie. path verbs], VMMI, and VMME that give them the most trouble. Specifically, this is because the acquisition of the argument and conceptual structure of these verbs requires specific negative evidence".

In the motion event that is the focus of the current study, the Figure (a bank robber) needs to cross a boundary, as he goes into a building (a bank), and the picture clearly shows that he does so in a specific manner, namely while running (see also appendix 1). The main choices open to speakers who are verbalizing this event are to use a deictic verb ( $g o$ ), a manner verb (run) or a path verb (enter). The argument structure of the English and the Spanish verbs overlaps in a number of ways, but there are also clear differences, as shown in Table 1. 
Transfer in manner and path in L2 Spanish

Table 1 Overview of constructions expressing "running (in)to" in Spanish and English

\begin{tabular}{|l|l|l|l|l|l|}
\hline Language & No boundary & Boundary crossing & \multicolumn{2}{l|}{} \\
& crossing & \multicolumn{2}{l|}{} \\
& manner or path verb+subordinate & Deictic verb + path verb (- manner \\
\hline Spanish & ir/correr a & entrar corriendo a/en & ir corriendo a & entrar a & $*$ \\
\hline English & go/run to & enters running & go running into & enter & run into \\
\hline
\end{tabular}

*Not available in Spanish due to the boundary crossing constraint

The first point we would like to make is that there is a wide range of options in English, but the most characteristic way to describe the event is to conflate motion and manner in the main verb and to express the boundary crossing with the help of the compound preposition into, which is in fact a combination of the satellite in and the preposition to, which are commonly written together as into. The preposition and the following ground element (the bank) can be omitted in structures such as he runs/goes in. Patterns that are typical for V-languages (enter or enter running or go running) are possible in English but generally assumed to be less frequent. In English into is not used with the path verb enter, but it is used with both deictic verbs such as go and manner verbs such as run or rush. In Spanish prepositions are used to express the movement towards or the position with respect to a particular Ground.

The Spanish preposition $a$ is exclusively goal-denoting (Zubizarreta \& Oh, 2007, p. 152). It can be used with deictic and path verbs, as in (17) and (18).

(17) Juan fue a París (Zubizarreta \& Oh, 2007, p. 152) 
Transfer in manner and path in L2 Spanish

'Juan went to Paris.'

(18) Juan entró [motion + path] al salón (Zubizarreta \& Oh, 2007, p. 152)

'Juan went into (entered) the living room.'

Using the preposition $a$ with manner of motion verb, as in (19), hardly ever occurs in

standard Spanish, although according to Zubizarreta \& Oh (2007, p. 154) there are subtle differences between speakers with respect to grammaticality judgements of some structures with manner verbs.

(19) Juan nadó ${ }_{[\text {motion + manner] }}$ al barco (directional interpretation) (Zubizarreta \& Oh, 2007, p. 154)

'Juan swam to the boat.'

To summarize the uses of manner verbs, in Spanish a manner verb such as correr can be used with the prepositions $a$, hacia (directional interpretation) and en, in which case the adjunct does not have a directional reading, but only a strictly local interpretation. The verb correr en means "to run around/inside" (see also Cadierno \& Lund, 2004, p. 146). It is not possible to interpret (20) with a directional meaning.

(20) Juan corrió $[$ motion + manner] en la casa (location)

'John ran inside/around the house.' (not: "he ran into the house”)

To express the idea of a boundary crossing into the bank, a path verb or a deictic verb needs to be used with a preposition. The preposition on its own does not convey the meaning of boundary crossing. This issue is very important for our study, because Spanish thus allows 
Transfer in manner and path in L2 Spanish

fewer possibilities than English in constructions of motion events: Spanish does not allow directional readings of manner-of-motion verbs with PPs, and it is thus a subset of English with respect to these structures. The situation is thus similar to that described for Englishspeaking learners of Japanese (Inagaki, 2001).

Finally, the verb correr has various other uses in Spanish as illustrated in (21-22).

(21) El tiempo corre

'Time flies.'

Corre can also be used as a discourse marker as an example from Davies' (2002) Corpus del español (CDE) demonstrates.

(22) ¡ Corre, corre! ; Corre, corre! Te - te voy a dar una poesía para que ligues 'Hurry up, hurry up! Hurry up, hurry up! I will give you-you a verse to flirt.'

Note that in (22) this verb is used without any elements that add ground or directionality to it. According to Slobin (2004) manner is more or less a luxury in V- languages, i.e. Vlanguages have fewer manner verbs and speakers of V-languages do not focus in manner when reporting motion events. In general terms, Berman \& Slobin (1994) make the observation that speakers of S-languages pay more attention to manner whereas speakers of V-languages pay more attention to stage setting, such as locative expressions or descriptions of the internal state of protagonists which allow the listener to infer the manner of movement, as in (23) from Cadierno \& Ruiz (2006).

(23) Salió como un rayo de la casa. 
Transfer in manner and path in L2 Spanish

'(She) left the house as lightning.'

Hence, there is a wider variety of manner verbs in S-languages and speakers of these languages focus more on this feature than speakers of V-languages.

Manner verbs are indeed fairly rare in spoken and written corpora as a data search in the CDE (Davies, 2002) shows. A search in this corpus shows that the deictic verb ir and its inflected forms appear 6.649,6 per million words (pmw), the path verb entrar $451.7 \mathrm{pmw}$ and the motion verb correr $122.1 \mathrm{pmw}$ in the oral texts (>22 mio. words). As a matter of fact, 303 forms of correr are found in the entire oral corpus of Davies but only 116 of corriendo, of which 25 are of ir corriendo and 25 of salir corriendo. There are no occurrences of entrar corriendo. In the case of ir corriendo (24), the meaning of the verbal paraphrase is "to rush" and not "to run". It is not implausible that learners confronted with this use infer that adding ground or directionality is licit in Spanish with the verb corre without realizing that these constructions do not involve a boundary crossing.

(24) Iba corriendo a la cocina

'(He/she) rushed to the kitchen.'

The following examples (25-26) show how correr is used with the meaning "to run", in the corpus of oral Spanish of Davies, although these particular examples do not have a boundary constraint reading.

(25) Corrió de los llanos hasta la montaña

'(He/she) runs from the valley to the mountains.' 
Transfer in manner and path in L2 Spanish

(26) Tampoco corren las educadoras

'The teachers do not run either.'

Hence, correr and its forms have a higher representation in quantitative terms than $V+$ corriendo in this corpus. Moreover, the frequency use of verbs such as entrar is much higher, even if the corpus does not contain conversation. The difference in frequency might explain why the learners acquire the two verbs in a different way. That is to say that there are extremely few instances in which correr is used in boundary crossing situations in spoken Spanish. In summary, the deictic ir is far more frequent than the motion verb entrar and the latter more frequent than the manner verb correr. The probability that a learner will be confronted with a verb such as ir in spoken Spanish is therefore much higher than the likelihood s/he comes across corriendo. Hence, the higher frequency of the verb deictic verb ir may explain why learners initially use this verb in motion event construals, as Phillips (2003) has demonstrated.

As regards teaching in the Spanish syllabus, grammatical areas such as por-para, serestar, verb morphology or gender are the main focus of the Spanish syllabus since they are viewed as difficult or problematic fields by teachers of Spanish. Cadierno (2004) points out that motion verbs are a rather neglected area in the Spanish teaching curriculum: she notes that this grammatical domain is widely ignored in the Spanish teaching manuals available in Denmark. If we look at British grammars of Spanish, we can conclude with Cadierno (2004) that this domain is non-existent for grammars published in the UK. For the present study we can say that the issue of manner and motion was not taught in any systematic way in the Spanish lessons which were taken by the participants. There was consensus amongst teachers teaching the groups studied that the issue of motion verbs was not a teaching priority. Thus motion event constructions were not taught and, if feedback on errors was to be given, the core areas of grammar were the focus of this type of negative evidence rather than event construals. 
Transfer in manner and path in L2 Spanish

\section{Transfer in the $\mathbf{L} 2$ acquisition of motion in Spanish}

The issue of transfer in the acquisition of motion event construal in L2 Spanish has been studied so far by Cadierno and colleagues, Navarro \& Nicoladis (2005) and Philips (2003). Cadierno (2008b) provides an overview of the research on acquisition of motion verbs to date. Cadierno \& Lund (2004) discuss the implications for Danish learners of Spanish and viceversa for Spanish learners of Danish.

Based on Talmy and Slobin's framework, Cadierno \& Lund (2004) and Cadierno (2004) hypothesized that if L1 transfer is important in the L2 acquisition of manner, one would expect Danish learners of Spanish to make more use of alternative ways to express manner in Spanish than native speakers (e.g. subordinate manner clauses, adverbial expressions or descriptions of internal mental states), because Danish has a wide range of manner verbs and speakers of Danish are used to focus on manner. Furthermore, it was hypothesized that Danish learners of Spanish would produce non target-like verbs that would conflate manner and motion in boundary-crossing situations. On the basis of her study of written frog stories of sixteen learners and sixteen native speakers of Spanish, Cadierno (2004) concludes that Danish learners of Spanish do not transfer conflation of manner and motion to their IL, although this is common in their L1. In terms of transfer Cadierno (2004) concludes that some domains of grammar such as the degree of elaboration of path of motion are transferred, whilst others such as event conflation are not transferred. Interestingly, Cadierno reports that Danish L2 learners of Spanish use redundant adverbs in combination with non-directional verbs of movement, such as mover "move" or ir "go", as in mover abajo "go down" and irse arriba "go up". In addition, she reports that Danish learners produce a type of construction that violates the boundary crossing constraint, as in saltar (a)fuera de la ventana "jump out of the window". She gives two explanations for these uses; on the one hand, she interprets them as evidence for transfer from the L1 and on the other hand as a 
Transfer in manner and path in L2 Spanish

strategy to fill in a lexical gap. That is to say, the learners who are not acquainted with subir "go up" use irse arriba instead.

Cadierno (2004) observes that native speakers of Spanish and native speakers of Danish use almost identical number of types in their respective mother tongues (see also Cadierno \& Ruiz, 2006). This result contradicts Berman \& Slobin's (1994) observation that speakers of S-languages use more motion verbs than speakers of V-languages. Cadierno argues that the differences found might reflect different methodological approaches, i.e. Berman \& Slobin collected oral data whereas Cadierno collected written texts. She argues that native speakers of Spanish use synonyms in the texts, which shows that they take care to produce a stylistically well written text. Contrary to expectations (Berman \& Slobin, 1994), Cadierno found that native speakers of Spanish use both static descriptions and phrases denoting trajectories almost equally frequently. According to Cadierno, these results show that there is unexpected variability in native Spanish as to the conceptualization of path. Cadierno (2004) concludes that the L1 influences the L2 but not in any consistent way. That is to say, whilst some areas of knowledge are transferred from the L1 to the L2 others are not. Danish learners of Spanish tend to elaborate more on the path than native speakers do, and are less inclined to conflate path and motion in Spanish. Cadierno attributes this to the learners' perception of the distance between Spanish and Danish, although this was not tested.

Cadierno \& Ruiz (2006) also investigated whether the L1 affects the way motion is expressed in L2. They compared the performance of Danish students learning Spanish and Italian students learning Spanish, which, in turn, was compared to the performance of an equal number of native speakers. The data were elicited with the help of the frog story. The issues investigated by the scholars were whether native speakers of Spanish mapped path and manner differently than Italian and Danish learners of Spanish. As expected, Italian learners of Spanish differ significantly from Danish learners in the way they use ground expressions with motion verbs. The latter use significantly more ground specifications than the former. As 
Transfer in manner and path in L2 Spanish

to manner of motion, no significant differences were found between Italian and Danish learners, and therefore Cadierno \& Ruiz conclude that the L1 does not impact on L2 performance for these learners. Navarro \& Nicoladis (2005) also found that English-speaking L2 learners of Spanish had almost fully acquired target-like patterns of motion expression.

It is possible that British learners of Spanish experience more transfer from their L1 than Danish learners of Spanish, because there is more overlap between the expressions of motion in English and Spanish (see also Table 1). As Cadierno \& Lund (2004) point out, Danish lacks English Latinate verbs such as enter, ascend, and descend, where Motion and Path are conflated. If it is true that partial overlap between languages triggers transfer, as Adjémian (1983) and White (1991) claim, higher degrees of overlap may lead learners to wrongly assume that the expression of motion in L1 can simply be transferred to L2.

Some evidence that transfer does indeed play a role in the L2 acquisition of motion in Spanish can be found in Phillips (2003), who assumes that learners who transfer their L1 setting in the domain of motion to their L2, risk overgeneralizing because they are unaware of the boundary crossing constraint (see section 2). As White (1991) and Inagaki (2001) have shown, overgeneralization is more difficult to overcome for non-native speakers than undergeneralization, because there is no positive evidence in the input to help learners discover that the ungrammatical form (a manner verb with a directional PP) is impossible in the target language. Phillips observes that his beginners use deictic verbs to express motion more often than the intermediate learners, whereas native speakers of Spanish make least use of this strategy. The latter predominantly use path verbs as well as manner verbs. The frequency of manner verbs is higher among the intermediate learners than among the beginners. It is not clear unfortunately how frequently the students use manner verbs for the expression of boundary crossings in this data set.

Additional evidence for the fact that transfer has an impact on the L2 acquisition of motion can be found in work on the L2 acquisition of English and Japanese (Inagaki, 2001). 
Transfer in manner and path in L2 Spanish

In addition, Treffers-Daller \& Tidball (2009) show that beginners as well as advanced L2 learners of French with English as their L1 continue to conflate manner and motion. Whilst advanced learners of French use more path verbs in crossing boundary situations than the beginners, the expression of manner in a satellite is still problematic at this stage.

\section{Hypotheses}

In the present study we hope to build on the important work of Cadierno and colleagues, and Phillips (2003) and provide further evidence about the role of the L1 in the L2 acquisition of motion by studying how British learners of Spanish construe motion events. As the number of informants in both Cadierno (2004) and Cadierno \& Ruiz (2006) was rather small (sixteen per group) and the test result for the differences between the three groups approaches significance $(\mathrm{p}=0.0774)$, we believe it is important to carry out a new study of the L2 acquisition of path and manner in Spanish. The focus of our study will be in particular on boundary crossings, as the L1s of British learners contrast clearly with their L2 at this point.

Cadierno (2004) assumes that only some patterns of the L1 are present in early stages of language acquisition but these diminish as learners become more proficient. We aim to test the hypothesis that L1 transfer plays a role not only at the beginning stages but also in the advanced stages of the L2 acquisition of Spanish. We assume this to be the case in particular for expressions of boundary crossings which involve manner verbs. As we have seen in section 3, Spanish is a subset of English in that it disallows directional readings of manner-ofmotion verbs with PPs, and L2 learners of Spanish will not be able to progress in their learning of these constructions on the basis of positive evidence alone. We assume that even advanced learners will continue to have problems with these constructions. For this reason we test learners of different proficiency levels, as suggested by Cadierno \& Ruiz (2006). More 
Transfer in manner and path in L2 Spanish

specifically this study will fill a gap in our knowledge by testing the following hypotheses.

1. Acquiring the targetlike expression of path will be relatively easy for British learners of Spanish because there is positive evidence in the input about these constructions. Low level British learners of Spanish will tend to use deictic verbs and add path satellites more often than advanced learners (cf Phillips, 2003), but higher level learners will have acquired target-like path constructions. The existence of English has latinate path verbs may facilitate the learning of Spanish path verbs.

2.British learners of Spanish will find it more difficult to acquire the targetlike expression of manner because (a) manner has low salience in Spanish and learners will therefore encounter few examples of the target-like expression of manner in Spanish and (b) they cannot find evidence for the existence of the boundary crossing in Spanish on the basis of positive evidence alone and c) they do not receive negative evidence about the existence of the boundary crossing in Spanish. There will be no significant differences between lower and higher level learners with respect to the acquisition of manner: learners in both groups will continue to conflate motion and manner in the main verb and will use manner verbs in boundary crossing situations.

\section{Method}

In what follows we will describe the methodology used in the present paper.

\subsection{Participants}


Transfer in manner and path in L2 Spanish

The data were collected from 68 students who were studying Spanish in an institution of Higher Education in the UK. There were three groups: level 1 students $(\mathrm{N}=19)$, level 2 students $(\mathrm{N}=19)$ and level 3 (final year) students $(\mathrm{N}=30)$. The level 3 students had completed a placement of six months in Spain prior to the data collection. It was not possible to include a native speaker group in the analysis, but we have analyzed data from a corpus of Spanish (Davies, 2002) to find out how native speakers use the verbs under study. The students also filled in a C-test ${ }^{\mathrm{ii}}$ which made it possible to obtain independent information about their Spanish proficiency (see Table 2). This C-test was highly reliable (Cronbach's alpha $(n=6)=.904)$. The level 1 and the level 3 students differ significantly from each other in their Spanish proficiency $(\mathrm{t}=2.54, \mathrm{df}=50, \mathrm{p}<0.05)$. Unfortunately, too few level 2 students were present at the time of testing, so we will not be able to report on their scores.

Table 2. C-test scores in percent per level

\begin{tabular}{|l|l|l|l|}
\hline Level at UWE & Mean & N & St. Deviation \\
\hline 1 & 59.8 & 22 & 18.20 \\
\hline 3 & 70.2 & 30 & 12.48 \\
\hline Total & 66.3 & 57 & 15.3 \\
\hline
\end{tabular}

\subsection{Materials and procedure}

The participants were presented with Plauen's (1952 [1996]) story of the bank robber and were told to tell the story as naturally as they could with no time limitation. In a warming up 
Transfer in manner and path in L2 Spanish

session, the participants introduced themselves in Spanish and counted until 30. All students were told that the recording was done for research purposes and that the recording would not affect their final marks. The recordings were anonymized using a coding system whereby the participants were allocated a number, the letter S identified the Spanish language as well as a number in the first position ranging from one to three identified the level, so that the tapes are labeled as follows $1 \mathrm{~S} 016$.

All speech samples were transcribed by experienced transcribers using the CHAT format (MacWhinney, 2000). For the present study, we were interested in how the scene where the robber enters the bank is lexicalized by the students (see appendix one for the picture). The verbs used were classified as manner, path, deictic and alternative options (e.g. static descriptions with estar). The manner option had the suboptions [ \pm cross-boundary]. If a learner used a verb and s/he corrected herself/himself afterwards resulting in, for example, a path verb and a manner verb, we counted both options. The instances where the learners avoided describing the event were counted separately and labeled as avoidance strategy. This explains the discrepancy between the number of participants and the results obtained. As the focus of the current paper is on the expression of one event, the remaining material has not been used in the current article.

\section{Results}

Table 3 shows that there are strong similarities between the level 1 and the level 2 students: while many use path verbs to verbalize the event, there is also large number of students who use manner verbs or deictic verbs. No uses of manner verbs in the satellite are attested at these levels. The overall differences between the groups are not large enough to become significant in a Chi-square test, so we conclude that there is no significant difference between the ways in which students from different levels construe the event. 
Transfer in manner and path in L2 Spanish

Table 3 The realization of manner and path in the bank robber story by British L2 learners of Spanish of different proficiency levels

\begin{tabular}{|l|l|l|l|l|l|l|}
\hline & verbs & adjuncts & path verbs & Deictic verbs & Alternative & total \\
\hline Level 1 Spanish & $5(26.3 \%)$ & 0 & $7(36.8 \%)$ & $6(31.6 \%)$ & $1(5.3 \%)$ & 19 \\
\hline Level 2 Spanish & $5(26.3 \%)$ & 0 & $8(42.1 \%)$ & $5(26.3 \%)$ & $1(5.3 \%)$ & 19 \\
\hline Level 3 Spanish & $12(40 \%)$ & $4(13.3 \%)$ & $8(26.7 \%)$ & $5(16.7 \%)$ & $1(3.3 \%)$ & 30 \\
\hline
\end{tabular}

Interestingly, students of all levels use verbs that conflate path and motion to encode the event. Lower level students use verbs such as entrar in $28.6 \%$ of the cases and advanced students in $26.7 \%$ of the cases. In the case of low level learners, this can be a classroom effect, since motion is taught with path verbs early in the Spanish syllabus. Moreover, one should not underestimate the role that latinates may play in the acquisition of verbs that conflate path and motion. Although English is an S-language, English has verbs such as enter which are structurally identical to Spanish and phonetically very similar. Moreover, entrar is a regular and frequent verb in spoken Spanish, which is easy to learn. Contrary to our expectations, however, advanced learners who have spent more than six months in a Spanishspeaking country use path verbs in only $26.7 \%$ of the cases to describe the motion event depicted in the picture. A small number of these (13.3\%) involve a verb and a manner adjunct at level 3. Level 1 and level 2 learners do not add manner adjuncts to manner verbs.

Finally it is important to note that some students avoid describing the event and use alternative expressions, such as static expressions (e.g. the robber is in the bank) instead of dynamic expressions, but this is rare in all proficiency groups. The most proficient learners 
Transfer in manner and path in L2 Spanish

use this option in only $3.3 \%$ of the cases. The alternative structures used include static verbs such as estar or the deponens haber "to have" as well as transitive verbs such as atacar "to attack".

\subsection{Qualitative analysis}

In this section we will provide a more detailed description of the verbs the learners use at the various levels.

\section{Manner verbs}

Level 1 students use manner verbs only five times (27-31). The verb correr "to run" is involved in four instances, and (31) involves use of the verb andar "to walk".

(27) Corra corre ${ }_{[\text {motion + manner] }}$ en el banco

'Run run in the bank.'

(28) Corre $_{[\text {motion + manner] }}$ en un banco

'(He/she) runs in a bank.'

(29) Está corriendo ${ }_{[\text {motion + manner }]}[*]$ al banco

'Was running to the bank.'

(30) Está corriendo $[$ motion + manner] hacia [*] banco 
Transfer in manner and path in L2 Spanish

'(He/she) is running towards the bank.'

(31) Está andando $o_{[\text {motion + manner] }}$ en *la banco

'(He/she) is walking in the bank.'

In (27-28) the students use the preposition en "in", which results in a grammatical utterance, but it does not describe the depicted event: the utterance can only be interpreted as someone running inside the bank and not running someone running into the bank. In these cases, the students conflate manner and motion in the main verb and choose a locative prepositional phrase to refer to a path in order to describe the event of the bank robber entering the bank, which corresponds to the English way of expressing a boundary crossing. In (29) the student packs manner in the satellite and path in the preposition $a$, but the choice of the preposition is non-target-like, as manner of motion verbs are hardly ever used with this preposition.

The verbalization in (30) is closer to the target, even though the article is missing before the noun. The student uses hacia is used instead of $a$, which is possible in Spanish, although not very frequent in spoken language. The use of andando "walking" in (31) is non-targetlike, because andar is a manner of motion verb, which is normally combined with the preposition $a$. In addition, the gender of banco "bank" is masculine in standard Spanish. In three out of a total of five examples the learners choose to use the present continuous. Although these examples very much resemble $\mathrm{V}+$ manner adjunct, they are calques of the continuous forms of English. The learners are not placing manner in a satellite, but using the gerund to build a continuous tense, as the use of the copula ser attests. However, another interpretation could be that it is not the choice of preposition that is non-targetlike but the choice of verb estar. The student might well have intended a simple path verb such as entrar instead of the auxiliary estar generally combined with the preposition $a$, thus qualifying this example as a lexical gap. 
Transfer in manner and path in L2 Spanish

Level 2 students use the manner verb correr in $26.3 \%$ of the cases. Two examples are found with the preposition en, two further examples with hacia and $a$, and one example without a preposition. One student uses the manner verb andar with the preposition en. Interestingly, three out of five students use the gerund to express manner, which is the default in Spanish, but also possible in English. Interestingly, one student starts to tell the story and uses a substantivized manner verb but then she corrects herself and uses entrar, see (32). The preposition en is targetlike with entrar, but not with correr.

(32) Al correr, um *a entrar en el banco

'To run er to enter the bank.'

The most noticeable difference between level 1 learners and level 3 learners is that some of the latter conflate path and motion in the main verb, and pack manner in the satellite, as in (33 - 36), although the lexical choice does not always correctly depict the event. In (36) the manner of motion is encoded in an adverbial phrase and no boundary is predicated in the utterance.

(33) $*$ Sale $_{[\text {motion + path] }}$ corriendo $_{[\text {manner }]}$ eh en el banco

'(He) comes out running into the bank.'

(34) $*$ Se va $a_{[\text {motion }+ \text { path] }} \operatorname{corriendo}_{[\text {manner] }}$ en hacia [*] un banco

'(He) goes running towards a bank.'

(35) Viene [motion + path] corriendo ${ }_{[\text {manner }]}$ otro hombre

'Another man comes running.'

(36) Corre $_{[\text {motion + manner] }}$ por el la el niño muy rápidamente

'(He) runs for the the the child very fast.' 
Transfer in manner and path in L2 Spanish

However, and contrary to our expectations, the learners still conflate manner and motion in the main verb, which needs to be explained. To start with, some of the learners do not focus on the event of entering the bank at all. Four learners simply use the manner verb either with a place adjunct, as in (37) or on its own, as in (38-40), thus focusing on the manner of the motion.

(37) Que está corriendo ${ }_{[\text {manner] }}$ en la calle

'Who is running in the street.'

(38) Pues está corriendo $[$ manner]

'Then(he) is running.'

(39) Y hay un ladrón, corre ${ }_{[\text {manner] }}$

'And there is a burglar, run.'

(40) Hay un hombre um um *qui que está corriendo ${ }_{[\text {manner] }}$

'There is a man er er who who is running.'

More importantly, level 3 learners still use the preposition en (5 examples) with the manner verb correr, resulting in the wrong interpretation of the motion event but do not use the more target-like prepositions a/hacia/hasta that denote path or goal. Surprisingly level 3 learners still use prepositions to express path. In the following section we will look at the use of path verbs in more detail.

Path verbs

Learners of all levels use a variety of simple path verbs, such as entrar 'enter' and marchar, probably intended as marcharse 'leave', as well as the deictic verb ir 'go' and venir 'come'. 
Transfer in manner and path in L2 Spanish

Level 1 use ir (8) entrar (1) venir (1), and an English verb, namely goes. As regards level 2, they use entrar (8) and marchar (1). Not surprisingly, level 3 learners opt to use the path verb entrar in most cases (11 out of 12). Only one learner uses the verb ir. These data show that level 1 and level 2 students use the verb entrar in $61 \%$ of the cases. It is almost the only verb of this type found among level 3 students (92.3\% of all motion expressions used). Hence, learners with extended exposure to Spanish are more native-like.

\section{Deictic verbs}

The deictic verb ir "go" is the only deictic verb used at all levels. Its use steadily decreases as the learners become more proficient. The decrease in use of deictic verbs is fully expected, as has been argued in section 2, and it confirms the findings of Phillips (2003).

\section{Discussion}

The first hypothesis of this study was that that acquiring the target-like expression of path would be relatively easy for British learners of Spanish because there is positive evidence in the input about these constructions. We assumed low level British learners of Spanish to use deictic verbs and to add path satellites more often than advanced learners (cf Phillips, 2003), and higher level learners to have acquired target-like path constructions. The second hypothesis was that British learners of Spanish would find it more difficult to acquire the target-like expression of manner. We expected lower and higher level learners to continue to conflate motion and manner in the main verb and to use manner verbs in boundary crossing situations.

In this study, no significant differences were found between students of different levels 
Transfer in manner and path in L2 Spanish

with respect to their use of manner or path verbs. All learner groups make use of path verbs but the most advanced group uses fewer of these than the lower level groups. Thus, there is no evidence for an increased use of path verbs from level 1 to level 3. Apparently, L2 learners of Spanish discover relatively early that path is encoded in the verb in a V-language as opposed to in a satellite. One possible explanation could be that English does have verbs of Latin origin that conflate motion and path such as enter, ascend and descend. Although they are not very frequent in everyday language, they are rather common in written texts. Hence, this fact may facilitate the acquisition task. But the frequency of the path verbs could also be a classroom effect. As the recordings were made after two to three months of instruction in Spanish, it is plausible that this result is a classroom effect. Verbs such as entrar are taught very early in the syllabus. However, the learners do not make an overwhelming use of such verbs to refer to the bank robber's movements.

While contrary to our prediction the use of path verbs does not show a clear development among our learners, the drop in the use of deictic verbs from level one $(31.6 \%)$ to level 3 (16.7\%) confirms the findings of Treffers-Daller \& Tidball (2009) for L2 learners of French, and Phillips (2003) for L2 learners of Spanish.

The results do provide some evidence for the second hypothesis. Conflation of manner and motion is common at all levels, and particularly frequent at level 3, despite the fact that the learners had been on a placement to a Spanish-speaking country prior to the data collection. Learners at the lower levels never encode manner in the satellite, but the level 3 students produce a few of these constructions. If lower level learners opt to express manner, they generally choose correr or andar in combination with a path or locative preposition (either a/hacia or en). As we have seen in section 2, the combination of a manner verb and hacia is possible in Spanish, but not frequent in everyday language because it entails a non boundary crossing event. This is an option that is more frequent in literary texts as examples from the Davies (2002) corpus reveal. This finding shows that students transfer the lexical 
Transfer in manner and path in L2 Spanish

information from the English verb onto the Spanish translation equivalent. The combination of the verb correr with en is possible, but has a reading that the students are not intending in describing the target event. The preposition en combined with a manner verb does not describe a boundary crossing event. It can only be interpreted as an action which takes place at one location. Level two students still use correr en instead of correr hacia, although the frequency of the former decreases among the more proficient learners.

The encoding of manner in a satellite in boundary crossing contexts seems to pose enormous difficulties for all learners. Only four level 3 students are able to correctly encode manner in the satellite in the present study. The target-like way to encode manner through an adjunct seems to be extremely difficult to acquire for learners of S-languages, despite the fact that structures such as He comes running into the bank are possible in English. Many learners appear to literally translate the English verb categorization frame into Spanish and add the prepositional phrase that encodes the boundary. The result is a manner verb with a preposition that denotes a direction (a/hacia) or a goal (hasta) rather than a boundary crossing. Even at level 3, many L2 learners of Spanish are not aware that path must be encoded in the verb in a V-framed language, and do not appear to be aware of the boundary crossing constraint either, because they also conflate manner and motion in the verb in a situation where a boundary is crossed.

The key question we wanted to answer in this paper was whether transfer can explain our data. As there are no significant differences between learners at the three levels, and many students have enormous difficulties to express manner in a target-like way in Spanish, we believe there is evidence for this hypothesis. Learners at all levels frequently conflate manner and motion in the main verb, leaving path to be expressed in an adjunct. The most plausible explanation for the students' choices is that they transfer the English ways to express motion to Spanish, yielding non-target-like results. It is only at level 3 that some learners begin to encode manner in the satellite, thus demonstrating an awareness of the boundary crossing 
Transfer in manner and path in L2 Spanish

constraint. Furthermore, the learners often use the preposition en with correr resulting in correr en, which is probably a calque of run in/into. In other words, even advanced learners of Spanish make use of transfer strategies, a finding which contradicts various studies by Cadierno for Danish learners of Spanish.

The issue that arises now is why British learners of Spanish take so long to learn how to express motion in Spanish. The lack of positive and negative evidence is likely to play an important role in this, although the research to date has been not able to quantify its impact. As to the issue of positive evidence, it is hardly possible to measure the exposure to the L2 learners, because learners are not only exposed to Spanish in classroom contexts. Some learners may have access to other input sources which may reinforce only certain grammatical domains whereas other learners have access to other sources whereby they reinforce different grammatical domains from the first group or none.

Although level 3 learners had been exposed to Spanish in a Spanish-speaking country for at least six months before the present study took place, the learners might or might not have been confronted with manner verbs in any meaningful way during their placement. The data from the Davies corpus show that manner verbs such as correr are rare in Spanish, in comparison with path verbs such as entrar, and that expression of manner in a subordinate clause (e.g. ir corriendo) are used very infrequently in the corpus. Hence we can assume that the learners' exposure to the appropriate use of the manner verb correr in spoken or written language has been minimal.

The existence of latinate verbs such as enter, ascend or descend in English may actually function as a double-edged sword: on the one hand it facilitates the acquisition of the targetlike construction of path by L2-learners of Spanish, which explains why British learners use target-like path verbs at an earlier stage than we expected. On the other hand, latinate path verbs may trigger increased transfer as the overlap between the ways in which Spanish and English speakers construe motion events is greater than the overlap between the ways in 
Transfer in manner and path in L2 Spanish

which these events are construed in Spanish and Danish. British learners of Spanish may therefore be more inclined to believe in the similarity of the expressions of motion in their two languages than Danish learners of Spanish, as latinate path verbs do not exist in Danish (Cadierno \& Lund, 2004).

Our results are partly in contradiction with Treffers-Daller \& Tidball's (2009) results. They studied a group of native speakers of English learning French, another V-language. The percentage of manner verbs increases considerably in Spanish, whilst it decreases in French. This result is unexpected in Spanish. The majority of learners have not acquired the boundary crossing constraint even after the placement in a Spanish speaking country.

One may wonder why the placement in Spanish did not lead to successful acquisition of this feature. We believe that the absence of negative evidence (implicit or explicit) is the key explanation for our results. During their placement students are unlikely to have obtained much positive evidence about the ways in which manner is expressed, because manner has low salience in Spanish. The non-occurrence of manner verbs with directional path satellites in everyday language is insufficient for students to discover that these constructions are impossible in Spanish. As to explicit negative evidence, the participants learned Spanish in the classroom, but they have received little negative evidence in this specific domain. The teaching of Spanish grammar at UK universities mainly focuses on several core components, i.e ser vs. estar, por vs. para, gender, and verb forms. The contrasts in the encoding of path or manner in English and Spanish do not belong to the core problems of Spanish grammar. Hence, it is likely that very little time has been devoted to its explicit teaching if any at all. Moreover, when correcting errors teachers generally focus on the well-known problems of Spanish grammar mentioned above and ignore minor errors that any native speaker of Spanish would classify as "sounds funny".

A limitation of the present study is that we were not able to recruit native speakers of Spanish, which could have given us some information about the ways in which native 
Transfer in manner and path in L2 Spanish

speakers of Spanish would construe this motion event. Instead, we have a quantitative and a qualitative analysis of the use of the target verbs in Davies (2002) corpus, which provided us with highly relevant information about the kinds of structures in which these verbs are used.

In summary, the current data provide evidence for the key role of L1 transfer in L2 acquisition as claimed by Schwartz \& Sprouse (1996). Moreover, and in line with Lefebvre, White \& Jourdan (2006), the L1 impacts on the IL for a long time especially in domains where input provides scarce evidence for a given phenomenon. Even the placement abroad does not contribute to the mastery of target-like expressions of manner in the L2 for many of our informants. Students rely on transfer to express manner more than to express path, probably because there is not enough positive evidence in the input and because students would need more negative evidence to acquire the boundary crossing constraint. These results therefore confirm Lefebvre, White \& Jourdan's (2006, p. 10) observation that transfer involves the adoption of the L1 grammar as the appropriate analysis unless and until there is evidence to the contrary. In the absence of such evidence, L1 effects will persist even in the L2 advanced state. 
Transfer in manner and path in L2 Spanish

\section{References}

ADJÉMIAN, C. (1983). The transferability of lexical properties. In S. Gass \& L. Selinker (Eds.), Language transfer in language learning (pp. 250-268). Rowley: Newbury Home.

AL-ANSARI, S. (2001). Two types of language exposure as predictors of student academic success in EFL: A case study of undergraduate students at the University of Bahrain. Language and Translation, 13, 91-108.

BEAVERS, J., LEVIN, B. \& THAM, S.W. (2010), The typology of motion expressions revisited. Journal of Linguistics, 46, 331-377.

BERMAN, R. A., \& SLOBIN, D. I. (1994). Relating events in narrative: A crosslinguistic developmental study. Hillsdale, NJ: Lawrence Erlbaum Associates.

BIRDSONG, D. (1987, December). A role for negative evidence in second language acquisition? Paper presented at the Annual Meeting of the Linguistic Society of America (San Francisco, CA). 27-30. Available from: http://www.eric.ed.gov/PDFS/ED292358.pdf.

BIRDSONG, D. (2005). Nativelikeness and non-nativelikeness in L2A acquisition. IRAL, 43, $319-328$. 
Transfer in manner and path in L2 Spanish

BLEY-VROMAN, R. (1989). The Logical Problem of Foreign Language Learning. In S. Gass \& J. Schachter (Eds.), Linguistic Perspectives on Second Language Acquisition (pp. 41-68). Cambridge: Cambridge University Press.

CADIERNO, T. (2004). Expressing motion events in a second language: a cognitive typological perspective. In: M. Achard \& S. Niemeier, Cognitive Linguistics, Second Language Acquisition and Foreign Language Pedagogy (pp. 14-49). Berlin: Mouton de Gruyter.

CADIERNO, T. (2008a). Motion events in Danish and Spanish: A focus on form pedagogical Approach. In: S. De Knop \& T. De Rycker (Eds.), Cognitive Approaches to Pedagogical Grammar (pp. 259-294). Berlin: Mouton de Gruyter.

CADIERNO, T. (2008b). Learning to talk about motion in a foreign language. In P. Robinson \& N. C. Ellis (Eds.), A handbook of cognitive linguistics and SLA (pp. 378-406). London: Routledge.

CADIERNO, T. \& LUND, K. (2004). Cognitive linguistics and second language acquisition: motion events in a typological framework. In: B.VanPatten, J. Williams, S. Rott \& M. Overstreet (Eds.), Form-Meaning Connections in Second Language Acquisition (pp. 139-154). New Jersey: Erlbaum.

CADIERNO, T \& RUIZ, L. (2006). Motion events in L2 Spanish acquisition. Annual Review of Cognitive Linguistics, 4, 183-216.

DAVIES, M. (2002-). Corpus del español (100 million words. Siglo XIII-siglo XX). 
Transfer in manner and path in L2 Spanish

www.corpusdelespanol.org. [accessed 10 April 2009].

FEIST, M, ROJO, A. \& CIFUENTES, P. (2007). Salience and acceptability in Spanish manner verbs: A preliminary view. International Journal of English Studies, 7(1), 137148.

HENDRIKS, H., JI, Y. \& HICKMANN, M. (2009). Typological Issues Regarding the Expression of Caused motion: Chinese, English and French. In M.B. Vukanović \& L.G. Grmuša (Eds.), Space and time in language and literature (pp. 22-38). Cambridge Scholars Publishing.

INAGAKI, S. (2001). Motion verbs with goal PPs in the L2 acquisition of English and Japanese. Studies in Second Language Acquisition, 23, 153-170.

JOHNSON, J.S. \& NEWPORT, E.L. (1989). Critical period effects in second language learning: the influence of maturational state on the acquisition of English as a second language. Cognitive Psychology, 21, 60-99.

KLEIN-BRALEY, Chr. (1985a). A cloze-up on the C-test: A study in the construct validation of authentic tests. Language Testing, 2, 76-104.

LANGACKER, R. (1999). Grammar and Conceptualization. Berlin and New York: Mouton de Gruyter.

LARDIERE, D. (2007). Ultimate attainment in Second Language Acquisition: a case study. Mahwah, New Jersey: Lawrence Erlbaum. 
Transfer in manner and path in L2 Spanish

LEFEBVRE, C., WHITE, L. \& JOURDAN, Chr. (2006). L2 Acquisition and Creole Genesis. Amsterdam/Philadelphia: Benjamins.

MAYER, M. (1969). Frog where are you? New York : Dial books for young readers.

MACWHINNEY, B. (2000). The CHILDES project: Tools for analyzing talk. Mahwah, NJ: Erlbaum.

MONTRUL, S. \& BOWLES, M. (2008). Negative Evidence in Instructed Heritage Language Acquisition: A Preliminary Study of Differential Object Marking. In M. Bowles et al. (Eds.), Selected Proceedings of the 2007 Second Language Research Forum (pp. 252262). Somerville, MA: Cascadilla Proceedings Project.

MORIMOTO, Y. (2001). Los Verbos de Movimiento. Madrid: Visor Libros.

NAVARRO, S. \& NICOLADIS, E. (2005). Describing motion events in adult L2 narratives. In D. Edington (Eds.), Selected Proceedings of the $6^{\text {th }}$ Conference on the acquisition of Spanish and Portuguese as first and second languages (pp. 102-107). Somerville MA: Cascadilla Proceedings Project.

ÖZÇALIŞKAN, S. \& SLOBIN, D. I. (1999). Learning How to Search for the Frog: Expression of manner of motion in English, Spanish, and Turkish. In A. Greenhill, H. Littlefield \& C. Tano (Eds.), Proceedings of the 23rd Annual Boston University Conference on Language Development (pp. 541-552). Somerville, MA: Cascadilla Press. 
Transfer in manner and path in L2 Spanish

ÖZÇALIŞKAN, S. \& SLOBIN, D. I. (2003). Codability Effects on the Expression of manner of motion in Turkish and English. In A. S. Özsoy, D. Akar, M. NakipoğluDemiralp, E. Erguvanl1-Taylan \& A. Aksu-Koç (Eds.), Studies in Turkish linguistics (pp. 259-270). Istanbul: Boğaziçi University Press.

PHILLIPS, L.T. (2003). Motion events in Spanish as a foreign language. MA thesis University of Pittsburgh.

PLAUEN, E.O. (1952; 1996). Vater und Sohn, Band 2. Ravensburg: Ravensburger Taschenbuch.

ROBINSON, P. \& ELLIS, N.C. (2008). Handbook of Cognitive Linguistics and Second Language Acquisition. New York and London: Routledge.

SCHRÖDER, K. \& STÜTZ, W. (Eds.) (1988). Der Bundeswettbewerb Fremdsprachen. Aufgaben, Lösungen und Kommentare aus den Jahren 1985 bis 1987. Berlin: Cornelsen.

SCHWARTZ, B.D. \& SPROUSE, R. (1996). L2 cognitive states and the full transfer/full access model. Second Language Research, 12, 40-72.

SLOBIN, D. I. (1996). From "thought and language" to "thinking to speaking". In J.J. Gumperz \& S.C. Levinson (Eds.), Rethinking linguistic relativit (pp. 70-96). Cambridge: CUP. 
Transfer in manner and path in L2 Spanish

SLOBIN, D.I. (2004). The many ways to search for a frog: linguistic typology and the expression of motion events. In S. Strömqvist \& L. Verhoeven (Eds.), Relating events in narrative: Vol 2. Typological and contextual perspectives (pp. 219-257). New York: Erlbaum.

SLOBIN, D.I. (2006). What makes manner of motion salient? Explorations in linguistic typology, discourse and cognition. In M. Hickman \& S. Robert (Eds.), Space in languages: Linguistic systems and cognitive categories (pp. 59-81). Amsterdam: John Benjamins.

SLOBIN, D. I., \& HOITING, N. (1994). Reference to movement in spoken and signed languages: Typological considerations. Proceedings of the Twentieth Annual Meeting of the Berkeley Linguistics Society (pp. 487-505). Berkeley: Berkeley Linguistics Society.

STRINGER, D. (2005). Paths in first language acquisition: motion through space in English, French and Japanese. PhD thesis, University of Durham.

TALMY, L. (1985). Lexicalization patterns: Semantic structure in lexical forms. In T. Shopen (Ed.), Language typology and syntactic description, vol. 3: Grammatical categories and the lexicon. Cambridge: Cambridge University press.

TALMY, L. (2000a). Toward a cognitive semantics, Vol I, Toward a Cognitiv Semantics: Concept Structuring Systems. Cambridge MA: MIT Press.

TALMY, L. (2000b). Toward a cognitive semantics, Vol II Toward a Cognitive Semantics: Typology and Process in Concept Structuring. Cambridge MA: MIT Press. 
Transfer in manner and path in L2 Spanish

TREFFERS-DALLER, J. \& TIDBALL, F. (2009, September). Learnability and event construal among French learners of English and English learners of French. Eurosla, Cork 1-3 September 2009.

TRUJILLO, C. (2001). Die Rolle der Sonorität im phonologischen Fremdsprachenerwerb. Der Erwerb des deutschen Silbenreims von Muttersprachlern des Spanischen. Frankfurt: Peter Lang.

WHITE, L. (1991). Argument structure in second language acquisition. French Language Studies, 1: 189-207.

WHITE, L., VALENZUELA, E., KOZLOWSKA-MACGREGOR, M. \& LEUNG, Y-K. (2004). Gender and number agreement in nonnative Spanish. Applied Psycholinguistics, 25, 105-133.

ZUBIZARRETA, M.L. \& OH, E. (2007). On the Syntactic Composition of manner and motion. Massachusetts: MIT Press. 
Transfer in manner and path in L2 Spanish

Appendix 1

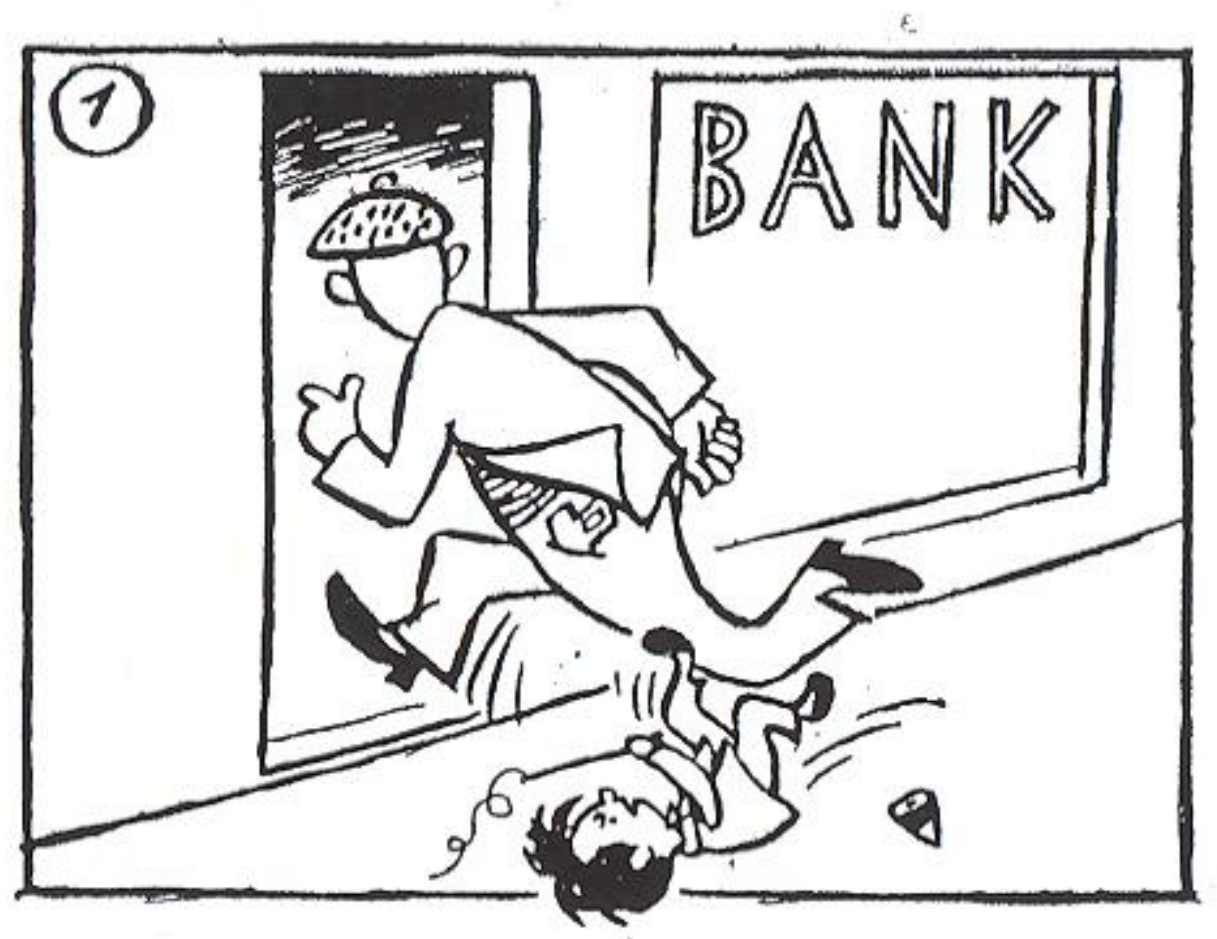

Source: Der Bankräuber (alias: Unbeabsichtigte Helden). From: E.O.Plauen (2000) Vater und Sohn, in Gesamtausgabe Erich Ohser (C) Südverlag GmbH, Konstanz. 
Transfer in manner and path in L2 Spanish

i It is possible to say volar fuera del nido "to fly out of the nest".

${ }^{i i} \mathrm{C}$-tests are variants of cloze test but differ from these in that the second half of every second word is deleted in a text. The C-test principle was developed by Klein-Braley (1985). It has been tested in a range of languages, including Spanish (Schröder and Stütz 1988). The C-test and the spoken data were collected during different lectures. This explains the discrepancies between the total numbers of participants in the former and the latter. 